\title{
PLEISTOCENE ICE AND RIVER EROSION IN THE SAINT CROIX VALLEY OF MINNESOTA AND WISCONSIN
}

BY WARREN UPHAM

(Read before the Society June 26,1900 )

\section{CONTENTS}

Page

.

The Saint Croix river and basin.............................. 14

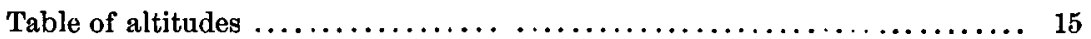

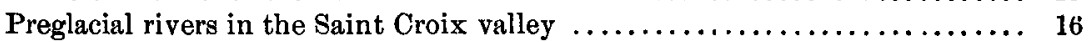

Pleistocene erosion of the Dalles .............................. 18

Outlet of the Western Superior glacial lake ...................... 21

Origin of lake Saint Croix and lake Pepin...................... 22

Summary of the geologic history of the Saint Croix Dalles $\ldots \ldots \ldots \ldots \ldots \ldots 23$

\section{INTRODUCTION}

The theme of this paper was first considered somewhat fully by the present writer in a lecture, March 18, 1896, entitled "The Saint Croix river before, during, and after the Ice age." This lecture was given at Taylors Falls, Minnesota, as one in a series designed to direct public attention to the Interstate park, recently set apart by legislative enactments of Minnesota and Wisconsin, on each side of the Saint Croix river at its Upper Dalles, closely adjoining the towns of Taylors Falls, Minnesota, and Saint Croix Falls, Wisconsin. The series of lectures was published in 1896 by Honorable George H. Hazzard, the Interstate Park Commissioner of Minnesota; but my lecture was withheld from publication in geologic literature, excepting very brief notes,* on account of my hope for further opportunities of field observation and study of this subject.

My chief conclusion, that in the Glacial period the Saint Croix river first began to occupy the part of its valley including the rock gorges of the Upper and Lower Dalles, was soon accepted by Doctor Charles P.

*Am. Geologist, rol. 17, p. 260, April, 1896, and vol. 18, p. 223, Oct., 1896. 
Berkey * and Mr A. H. Elftman, $\uparrow$ who each made extensive field studies of this district. They differ from me, however, in referring the erosion of the new part of the valley to late Glacial and postglacial time, instead of which it seems to me to belong to an interglacial stage or epoch. Probably its date was the same as that of the erosion of large watercourses in the drift-sheet of Martin county, on the southern border of Minnesota, which, having become in part and irregularly filled by later drift, are marked by three very remarkable chains of lakes. $\$$

Subsequently I have again several times examined the portions of this valley next below and above the Dalles, confirming the view that the new course of the river and much of its gorge erosion are referable to a long interglacial stage which in the Mississippi basin followed the Kansan stage of maximum glaciation.

During that time of extensive recession of the border of the ice-sheet, the Saint Croix river appears to have channeled this part of its valley and its gorges in the Dalles, thereby uniting two hydrographic basins, which previous to the Ice age had been each separately tributary to the Mississippi. After the readvancing ice-sheet had again reached southward nearly to its previous limit west of the Mississippi, and even beyond it in Illinois and eastward, this river during the final departure of the ice, in the closing Wisconsin stage of the Glacial period, carried for some time a much greater volume of water than now, being temporarily the outlet of a great lake dammed by the barrier of the northeastwardly receding ice border in the western part of the Lake Superior basin. The beds of the Saint Croix and Mississippi, southward from the Dalles, were then channeled considerably below their present depths, and by later partial refilling with sand and gravel they have come to be occupied in the unfilled portions by lake Saint Croix and lake Pepin.

\section{The Saint Croix River and Basin}

Measured along the general course of the valley, and without including the minor bends and meandering of the river, its length from source to mouth is about 150 miles. At first it runs southwestward about 75 miles; then east and southeast about 25 miles, to Taylors Falls, and, lastly, south about 50 miles. In the southern half of the distance last noted it is expanded to the width of a half mile to one mile, forming

* "Geology of the Saint Croix Dalles," part I, Am. Geologist, vol. 20, pp. 345-383, with maps and sections, Dec., 1897. This paper is continued by parts II and III, on the mineralogy and paleontology of the rock formations, in vol. 21, pp. 139-155 and 270-294, with maps and plates, March and May, 1898.

† “The Saint Croix River valley," Am. Geologist, vol. 22, pp. 58-61, July, 1898.

$\ddagger$ Geology of Minnesota, vol. 1, 1884, pp. 479-485, with map at page 472. 
the lake Saint Croix. Several large tributaries flow to the Saint Croix river from each side, and the maximum width of the drainage basin is about 80 miles, from the beginnings of the Kettle river in Minnesota southeast to the farthest springs of the Yellow river in Wisconsin.

According to $\mathrm{Mr}$ James L. Greenleaf, in his "Report on the water power of the Mississippi river and some of its tributaries," contained in volume 17 of the quarto final reports of the tenth United States census, for 1880, published in 1887, the drainage area of the Saint Croix comprises 7,576 square miles, of which slightly more than half lies in Wisconsin. The volume of the river at its mouth in the stage of low water is stated to be 2,800 cubic feet per second, and the average flow about 6,200 cubic feet per second for the whole year.

The chief tributaries from Wisconsin are the Namekagon river, stated by Greenleaf to be 85 miles long, draining an area of 1,025 square miles; the Yellow river, 50 miles long, draining 310 square miles; the Clam river, also 50 miles long, draining 416 square miles; Wood river, 30 miles long, draining 168 square miles; Apple river, 55 miles long, draining 427 square miles; and Willow river, 35 miles long, draining 246 square miles.

From Minnesota the Saint Croix receives the Kettle river, noted as 70 miles long, with the largest tributary drainage area, 1,093 square miles; the Snake river, 78 miles long, draining 937 square miles; and the Sunrise river, 30 miles long, draining 292 square miles.

\section{Table of Altitudes}

The following altitudes along the Saint Croix river, given in feet above the sea, from leveling by United States engineers in surveys for converting some of the abundant lakes of its head streams into a reservoir system, and from railroad surveys, show that the main stream has a descent of about 400 feet:

Springs at head of the South branch of the Bois Brule river.... . . . . 1,068

Springs at head of the Saint Croix river......................

(These springs rise in the same marsh, 600 feet apart, the Bois Brule river running north, the Saint Croix south. An ancient watercourse exists here, mainly abont a mile wide, bordered by drift bluffs 75 feet high, with their crests 1,140 to 1,150 feet above the sea. It was the outlet of lake Superior when the receding ice-sheet on the northeast, acting as a barrier to the present course of outflow, held this lake about 500 feet higher than now.)

Upper Saint Croix lake................................ 1,011

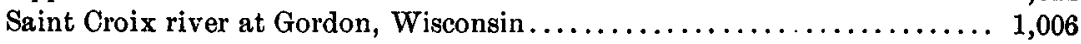

Same, low water, above and below the "Big dam" ..........., 1,005 and 1,001 
Same at Moose River rapids. $\ldots \ldots \ldots \ldots \ldots \ldots \ldots \ldots \ldots \ldots \ldots \ldots \ldots, \quad \begin{gathered}\text { Feet } \\ 987\end{gathered}$

Mo'sth of Namekagon river................................. 912

Mouth of Yellow river $\ldots \ldots \ldots \ldots \ldots \ldots \ldots \ldots \ldots \ldots \ldots \ldots \ldots \ldots \ldots, \quad 892$

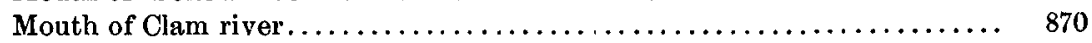

Head of Kettle River rapids (4 miles long, falling 49 feet)........... 858

Mouth of Kettle river, west of the "Big island "................. 824

Foot of Kettle River rapids............................... 809

Mouth of Snake river $\ldots \ldots \ldots \ldots \ldots \ldots \ldots \ldots \ldots \ldots \ldots \ldots \ldots \ldots \ldots \ldots$

At bridge of the Grantsburg branch, Saint Paul and Duluth railroad..... 775

At Rush City ferry.................................. 770

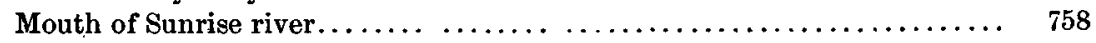

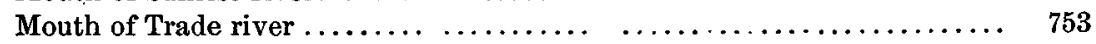

Head of Saint Croix rapids ( 6 miles long, falling 53 feet) $\ldots \ldots \ldots \ldots \ldots \quad 742$

Mouth of Big Rock creek............................... 726

Foot of Saint Croix rapids, at the town of Saint Croix Falls .......... 689

At Taylors Falls, the head of steamboat navigation, three-fourths of a mile

below the last $\ldots \ldots \ldots \ldots \ldots \ldots \ldots \ldots \ldots \ldots \ldots \ldots \ldots \ldots \ldots \ldots, 6, \ldots \ldots \ldots$

At head of Rock island........... .................... 685

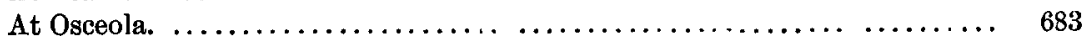

At bridge of the Minneapolis, Sault Ste. Marie and Atlantic railway, bed,

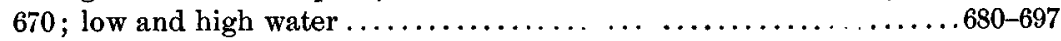

Mouth of Apple river ............................... $6 \mathrm{i}^{2}$

At bridge of the Wisconsin Central railroad, bed, 666 ; ordinary low stage

of water, 676 ; extreme low and high water..................6670-689

Lake Saint Croix (maximum depth, 25 feet), extreme low and high water,

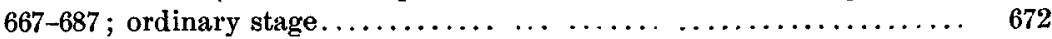

Junction with the Mississippi river at Prescott................. 667

\section{Preglacial Rivers in the Saint Croix Valley}

The very long Tertiary era, preceding the Ice age, had permitted the larger streams of Minnesota and Wisconsin to erode deep and wide, well matured valleyส, free from waterfalls or strong rapids, and having no narrow; rock-walled gorges, like the Dalles of the Saint Croix. But in the northern, drift covered part of the United States, and throughout Canada, the rivers, on their again coming into existence when the ice of the Glacial period melted away, found themselves in many places turned aside from their preglacial courses by the drift deposits and by the movements of continental uplift and subsidence that were associated with the Ice age. In some cases formerly independent streams were thus united to make a single larger river system; and often a river was turned out of its old drift-filled valley for a comparatively short distance, as a few miles, being there compelled to cut a new gorge in the bed-rocks.

One or the other of these results of the Glacial period has been well ascertained as the fortune of so many rivers in the great drift-covered 
region that the occurrence of the two short, grandly picturesque rock gorges, or canyons, known as the Upper and Lower Dalles of the Saint Croix, so named by the French voyageurs in allusion to their inclosing walls of rock, strongly suggests that there the stream is now flowing in a course which it has cut during and since the Ice age. No closely adjacent belt, however, seems to be probably identifiable as a drift-filled preglacial valley. Therefore, from my studies, for the Minnesota Geological Survey, of the country extending many miles westward from the Saint Croix, I conclude that in preglacial times this river was represented by two quite independent rivers, each flowing into the Mississippi.

The greater part of the Saint Croix drainage basin, including all above the rapids, six miles long, which end at Saint Croix Falls and Taylors Falls, I think to have belonged before the Ice age to a river flowing south and southwest from the principal elbow of the present Saint Croix, taking approximately the course of the Sunrise river, which, however, now runs northward, and traversing Anoka county to a junction with the Mississippi somewhere between Anoka and Minneapolis. Thence, as Professor N. H. Winchell has shown, the preglacial course of the Mississippi probably passed southeastward.* It may have coincided nearly with the site of lake Phalen, close northeast of Saint Paul, running thence south two miles to join the present valley near the State Fish Hatchery, where the northeastern bluff of the Mississippi for a distance of about a mile consists of morainic glacial drift without rock outcrops. Between lake Phalen and this place, a well at the Saint Paul Harvester works, about 863 feet above the sea, penetrated 235 feet of drift deposits before reaching the bed-rock, thus revealing the existence of a preglacial channel eroded there by a river that fiowed at a level 55 feet below the present Mississippi. $\dagger$

A broad, low belt of sand and gravel plains stretches across the distance of nearly 40 miles from the Saint Croix to the Mississippi at Anoka, nowhere having a greater height than 150 feet above the elbow of the Saint Croix and the mouth of the Sunrise river. On the east, between that low tract and the Saint Croix valley, a belt of rolling and hilly glacial drift or till underlain in part by the bed-rocks at a greater altitude than the sand and gravel area westward divides it from this valley. It seem to me more likely therefore that the old river passed far west and south, to Anoka and Saint Paul, than that it took the course sug-

\footnotetext{
* "An approximate interglacial chronometer," Am. Geologist, vol, 10, pp. 69-80, with sections and a map, August, 1892. On this map the probable preglacial and interglacial ehannels of the Mississippi in the vicinity of Minneapolis and Saint Paul are delineated, differing much from its present course.

† Geology of Minnesota, Final Report, vol. 2, 1888, pp. 361-363.
} 
gested by Mr Elftman, from the Sunrise river by Chisago lake to rejoin the present Saint Croix valley.

About a sixth part of the Saint Croix basin, lying east and south of Taylors Falls, appears to have been drained during the Tertiary era by a stream coinciding nearly with the Apple river and the lower 30 miles of the Saint Croix river. The large basin and river first described may be called the preglacial Saint Croix, and the lower small stream may be distinguished as the enlarged preglacial Apple river.

These Tertiary drainage areas, which by the vicissitudes of the Ice age became united into one stream, the present Saint Croix, I think to have been divided, up to the time of the ice accumulation in the Glacial period, by a watershed of the very old trappean and Cambrian rocks, extending from northeast to southwest across the sites of the towns of Saint Croix Falls and Taylors Falls.

\section{Pleistocene Erosion of the Dalies}

In the twenty-third annual report of the Minnesota Geological Survey for the year 1894 I have stated (on pages 188-190) the evidence that the recession of the ice-sheet during the Buchanan interglacial stage, which succeeded its Kansan stage of maximum area west of the Mississippi, extended northward beyond the site of Barnesville, Minnesota, on the southern part of the great valley plain of the Red river of the North. Probably at that time the ice had been melted away from nearly or quite all of the southern half of Minnesota. That the retreat of the ice-sheet had uncovered the southern third of the Saint Croix basin is shown, in Nessel township, Chisago county, Minnesota, near Rush City, by an interglacial Buchanan land surface, with wood and peaty matter, upon a deposit of modified drift that was laid down during the previous retreat of the ice.* Above the wood and peat of this place, and above an extensive plain of the Buchanan modified drift reaching thence several miles eastward, a somewhat uniform mantle of till, 10 to 20 feet deep, was spread during the ensuing Illinoian and Iowan glacial readvance.

We thus know that the district including the Dalles and extending northward at least to Rush City was uncovered from the ice-sheet during the Buchanan stage of the Glacial period. Later the increasing snowfall again permitted nearly all this basin to be enveloped by the ice of the Illinoian and Iowan stages, reaching on the Saint Croix river southeasterly to the conspicuous moraine belts which pass from Saint Paul and Minneapolis northeastward to the northern half of lake Saint Croix 
and through the southeastern part of Chisago county, continuing thence onward in Wisconsin.

Terraces of sand and gravel, which are found in the Saint Croix valley 4 to 10 miles north of Taylors Falls, mostly having a height of about 90 feet above the river, are remnants of valley drift deposited during the Wisconsin stage of the final departure of the ice-sheet. These gravel deposits, continuous as one expanse of modified drift from the "jack pine barrens" of northwestern Wisconsin, bear testimony that a part of the floods from the dissolving ice then passed southward along the present Saint Croix, and that the erosion of the valley in the vicinity of the Dalles had been mainly accomplished previous to the Wisconsin stage. We are led, therefore, to the conclusion that much channeling of the valley here, enlarging it along all its course from the Dalles southward to the Apple river, and eroding the drift bluff, an escarpment of till, which rises steeply on the west side of the valley at Taylors Falls and northward to the height of 200 to 220 feet above the river, took place mostly during the prolonged Buchanan interglacial stage. It was a nearly similar history with that of the Minnesota river during the same Buchanan time in the reexcavation of its valley, which had doubtless become chiefly filled with drift during the principal Kansan stage of glaciation.

When I wrote the chapter on this district for the final report of the Minnesota Geological Survey (volume 2, 1888, pages 399-425, with map of Chisago, Isanti, and Anoka counties), I believed that the preglacial and postglacial courses of the Saint Croix were alike; but I now attribute the establishment of this great river course and valley at the Dalles, and for many miles above and below, to the capricious outlines of the retreating ice-front in Buchanan time, probably sending a considerable stream across the preglacial watershed and along this course at first because the ice itself was still a barrier on the lower country westward. The erosion by this stream had cut down this section of the valley and the two gorges of the Upper and Lower Dalles so far before that lower land was uncovered from the ice that the channel so begun still continued as the lowest then available for the river, and the erosion apparently extended as deep as to the present river level before the renewal of ice accumulation.

The duration of the interglacial stage attended by great decrease of this part of the continental ice-sheet has been estimated by Winchell, from his investigation of the drift-filled gorge of the Mississippi west of Minneapolis, to have measured about 15,000 years.* Within that time,

\footnotetext{
* Paper before cited in the American Geologist (vol. 10), estimating the interglacial stage as 9,750 years; which is corrected to about 15,000 years in the same volume, p. 302, Nov., 1892.
} 
preceded and followed by long stages of glaciation of this district, the drainage from an embayment of the ice boundary. at the junction of glacial currents flowing in Minnesota from the northwest and in Wisconsin from the northeast, passed in a large river, the interglacial Saint Croix, across the former watershed where we now have the gorges of the Dalles.

Separate preglacial streams flowing from this locality southward and northwestward during many thousand years of the Tertiary era, in the now continuous river course, had doubtless performed the greater part of the valley erosion on each side of the old watershed, which itself, we may also believe, was deeply indented here by a col of the trappean rocks in which the Dalles are channeled. The separate valleys leading each way from the col, as eroded during the very long Tertiary era, may have attained nearly the same size which they now have as parts of the present continuous valley, varying mainly from about a half mile to one mile in width and from 75 feet to about 150 feet in depth below the adjoining rock cliffs.

In the Upper Dalles, at and just south of Taylors Falls, extending about two-thirds of a mile, and again in the Lower Dalles, situated two miles farther down the river and reaching one-third of a mile, immediately above the village of Franconia, Minnesota, the rock cliffs of trap, Keweenawan diabase, rise almost or quite perpendicularly on each side of the river, inclosing it at each place by a very picturesque gorge. The vertically jointed and castellated walls of the Upper Dalles form a gorge from 200 feet to about 500 feet wide, which turns at a sharp angle in its central part from a course nearly due south to another bearing westsouthwest. The course of the Lower Dalles, about 500 feet wide, is also west-southwest, this direction being in each case determined by a principal system of parallel and nearly vertical joint planes.

Between these diabase gorges the valley widens to about a mile, its western rock wall being an escarpment of almost horizontally bedded Cannbrian sandstone and shales, easily eroded, while on the east it is inclosed by irregular slopes of the igneous Keweenawan rocks. Continuing south from the Lower Dalles, the valley, a half mile to one mile wide, is inclosed by escarpments of the horizontal Cambrian sandstone capped by dolomitic limestone, with overlying glacial drift. Returning and going up the river from Saint Croix Falls, we find its valley there inclosed chiefly by eroded drift bluffs.

Glacial erosion in this part of the Saint Croix valley is supposed by Doctor Berkey to have been an important factor in causing the river at the end of the Ice age to take its present course. It seems to me, however, as before shown, that we may better regard the oppositely flowing 
preglacial streams and the interglacial Saint Croix as the chief agents of the valley sculpture. During the maximum Kansan glaciation the ice-sheet here was doubtless very efficient in planing down the rock surface, and it certainly aided to some degree in shaping the valley. It also acted in the same way during the Illinoian and Iowan stages. But for some time in the closing Wisconsin stage of that later glaciation this district, lying near the glacial boundary and its marginal moraines, was less powerfully pressed and worn beneath the thin ice border, and instead was characterized rather by drift deposition.

\section{Outlet of the Western Superior Glactal Lake}

In the western part of the basin of lake Superion the receding ice-sheet held a lake which outflowed southward through northwestern Wisconsin, across the present watershed, between the Bois Brulé and Saint Croix rivers. The highest shoreline of this lake at Duluth is 535 feet above lake Superior (which has a mean level 602 feet above the sea); on mount Josephine, about 130 miles northeast from Duluth, its height, according to leveling by Doctor A. C. Lawson, is 607 feet; and at L'Anse and Marquette, Michigan, 175 and 225 miles east of Duluth, it is found by $\mathrm{Mr}$ F. B. Taylor about 590 feet above the lake. The northeastward uplift averages seven inches per mile, and the eastward ascent is approximately three inches per mile.

The latest and lowest of the Western Superior beaches observed at Duluth, occupied by the "boulevard" or pleasure driveway, 475 feet above the lake, on the bluffs back of the eity, appears to have an ascent of only about 35 feet in the distance to mount Josephine, showing that the uplift of the land was quite rapidly in progress while the ice-front still maintained the lake at the Saint Croix outlet.

Not long after the glacial retreat passed eastward beyond mount Josephine and Marquette, this lake was lowered and merged with lake Warren across the lowlands of the northern peninsula of Michigan. The vertical interval between the final stage of the Western Superior lake and the level of lake Warren shown by its earliest beach at Duluth was about 60 feet. Thenceforward the outlet of lake Warren past Chicago carried away the drainage from the glacial melting and rainfall of the Superior basin.

The old channel of outflow to the Saint Croix river has a width of about a fifth of a mile in its narrowest place. Its bed is 1,070 feet above the sea, or 468 feet above lake Superior, and it is bordered by bluffs about 75 feet high, showing that when the course of outflow began here the Western Superior glacial lake was about 550 feet above the present 
lake level. Probably the highest part of the swamp now forming the watershed in the channel has been filled 20 to 25 feet since the lake forsook this mouth, which was thus lowered by erosion some 100 feet, from 1,150 to 1,050 feet, approximately, above the present sealevel.

\section{Origin of Lake Saint Croix and Lake Pepin}

Since the ice barrier which caused the glacial lake Agassiz and the Western Superior lake disappeared, the Minnesota valley and that of the Mississippi below their confluence, and also the Saint Croix valley below Taylors Falls, carrying only a small fraction of their former volume of water, have become considerably filled by the alluvial gravel, sand, clay, and silt, which have been brought in by tributaries, being spread for the most part somewhat evenly along these valleys by their floods. The changes produced by this postglacial sedimentation have been pointed out and ably discussed by General G. K. Warren, who thus added much to our knowledge of the geologic history of these rivers. Lakes Traverse, Big Stone, and Lac Qui Parle occupy hollows in the outlet of lake Agassiz due to inequalities of these recent deposits. At the mouth of the Minnesota river, the Mississippi has brought more sediment than its branch, which is thus dammed for a distance of 30 miles, to Little Rapids, with a depth of 20 to 25 feet at low water. In the same way the Mississippi valley at the mouth of the Saint Croix has become more filled by postglacial deposits than its tributary, which is thus held as back-water 20 miles, to the head of lake Saint Croix, which is 25 feet deep.

Lake Pepin, having a depth of about 60 feet, according to General Warren, lies in the continuation of the valley which was deeply channeled by the outflow from these glacial lakes, because it has become unequally filled below by the deposition of alluvium from the Chippewa river. The depths of lakes Saint Croix and Pepin, however, are only a partial measure of the channeling of the Saint Croix and Mississippi rivers during and shortly after the departure of the ice sheet. The greatest depth of the Saint Croix river, stated by Dr Berkey to be 160 feet near Angle Rock of the Upper Dalles, was worn down probably by the river when it flowed, at the end of the Ice age, along all its lower course, like the lower part of the Minnesota river and the Mississippi thence southward as well, about 100 to 150 feet beneath the present river bed.

Preglacial river erosion in the great valleys had reached far below their present depths, and additional deepening may have occurred during the early and greater part of the Ice age for the Mississippi in the Wisconsin 
driftless area and during the long interglacial stage for the more northern valleys. Epeirogenic depression in the Iowan stage, and the consequent melting of the ice-sheet, continuing in the Wisconsin stage and setting free the abundant englacial drift, caused these valleys to be deeply tilled by the deposits of the river floods. But soon these deposits were in turn deeply eroded by the rivers, especially where they were outlets of glacial lakes; and during the postglacial period they have been partly refilled, forming the lakes through which the Minnesota, Saint Croix, and Mississippi rivers flow.*

\section{Summary of the Geologic Higtory of the Saint Croix Dajles}

1. The earliest geologic events directly concerned in making the grand scenery of the Saint Croix Dalles were the eruption of lavas and their subsequent erosion to form steep ridges.

2. Against and on these trap formations, submerged under the Cambrian ocean, were deposited beds of sandstone and shale, which still have nearly their original horizontal position, and which contain shells and impressions of brachiopods and trilobites. The very valuable early geologic explorations and report of David Dale Owen erred in assigning the trap rocks to eruptions bursting through the Cambrian strata. Instead, the more thorough investigations of the Wisconsin and Minnesota geological surveys have ascertained that the trap rocks are the older. Both belong in the far distant geologic past, variously estimated by Dana, Walcott, and others to be some fifty or more million years old.

3. Many geologic periods rolled away, until, after having been long a land area, the western three fourths or perhaps more nearly all of Minnesota was depressed beneath the sea during the later half of the Cretaceous period.

4. Through the next ensuing Tertiary era, probably comprising some three to five million years, this region was again a land surface, and has continued so onward through the comparatively short Quaternary era, of probably 200,000 years, to the present time, excepting that during the Glacial period it was covered by the ice-sheet. 'Two entirely distinct Tertiary rivers drained the present Saint Croix basin.

5 . The obstructions of the ice-sheet during the Buchanan and Wisconsin stages of the Glacial period caused the Tertiary or preglacial

\footnotetext{
* Compare my paper, "The Minnesota valley in the Ice age," Proc. Am. Assoc. Adv. Sci., vol. 32, for the year 1883, pp. 213-231, noting alluvial deposits in a well at Belle Plaine, 150 feet below the present river, and the record of a well at Lake City, Minn., on lake Pepin, which penetrated beds of stratified clay and of gravel and sand, the modified drift swept into the Mississippi valley during the final recession of the ice-sheet, to the bed-rock about 170 feet below the level of the lak $\theta$ (Minn. Geol. Survey, Thirteenth Annual Report, for 1884, p. 58 ; Final Report, vol. 2, 1888, p. 17).
} 
Saint Croix river to become joined with the Tertiary Apple river. The Saint Croix, nearly as it exists at the present day, was thus an inheritance from the Ice age, beginning as an interglacial river perhaps some 40,000 years ago, and again during the final retreat of the ice-sheet, which here, according to estimates by Professor N. H. Winchell from the rate of recession of the falls of Saint Anthony, was about 8,000 years ago.

6. The erosion of the valley at the Dalles and for several miles from these gorges, both up and down the river, seems attributable in large part to preglacial streams flowing in opposite directions from a col of the Tertiary and early Quaternary watershed. These stream courses were made continuous by the interglacial Saint Croix. The gorge of the Upper Dalles has undergone further changes by late Glacial and postglacial stream erosion. Its walls have been much riven since the Ice age along the vertical joint planes, but they have suffered only very slight disintegration and decay through weathering.

7. Lakes Saint Croix and Pepin, besides Lac Qui Parle and Big Stone and Traverse lakes, are due to geologically recent and still progressing deposition of alluvium in these valleys, which were deeply eroded by the outflow from the Western Superior glacial lake and from lake Agassiz. The latest and present work of the Saint Croix river in both the Upper and Lower Dalles is to maintain very deep water there, due to the strong eroding current of the stream in times of flood, washing away the sand and gravel of its bed in these exceptionally narrow parts of the channel.

This paper attempts to give the broad outlines of the history of the Saint Croix river, and especially of its Upper and Lower Dalles, well known through these two states for their beautiful and even grand scenery. Other parts of the details of erosion in and near the Dalles remain for description and explanation in the following paper. To most visitors in the Interstate park, its peculiar rock sculpture to be next considered appears more singular and marvelous than the craggy gorges of the Dalles, the deep river, or the echoes from its cliffs. 